\title{
Geochemistry of rare earth elements in the Baba Ali magnetite skarn deposit, western Iran - a key to determine conditions of mineralisation
}

\author{
Hassan Zamanian, Kaikosrov Radmard* \\ Department of Geology, Faculty of Natural Sciences, Lorestan University, Khoram Abad, Iran \\ *corresponding author, e-mail: k_radmard@yahoo.com
}

\begin{abstract}
The Baba Ali skarn deposit, situated $39 \mathrm{~km}$ to the northwest of Hamadan (Iran), is the result of a syenitic pluton that intruded and metamorphosed the diorite host rock. Rare earth element (REE) values in the quartz syenite and diorite range between 35.4 and $560 \mathrm{ppm}$. Although the distribution pattern of REEs is more and less flat and smooth, light REEs (LREEs) in general show higher concentrations than heavy REEs (HREEs) in different lithounits. The skarn zone reveals the highest REE-enriched pattern, while the ore zone shows the maximum depletion pattern. A comparison of the concentration variations of LREEs (La-Nd), middle REEs (MREEs; Sm-Ho) and HREEs (Er-Lu) of the ore zone samples to the other zones elucidates two important points for the distribution of REEs: 1) the distribution patterns of LREEs and MREEs show a distinct depletion in the ore zone while representing a great enrichment in the skarn facies neighbouring the ore body border and decreasing towards the altered diorite host rock; 2) HREEs show the same pattern, but in the exoskarn do not reveal any distinct increase as observed for LREEs and MREEs. The ratio of La/Y in the Baba Ali skarn ranges from 0.37 to 2.89 . The ore zone has the highest La/Y ratio. In this regard the skarn zones exhibit two distinctive portions: 1 ) one that has $\mathrm{La} / \mathrm{Y}>1$ beingadjacent to the ore body and; 2 ) another one with $\mathrm{La} / \mathrm{Y}<1$ neighbouring altered diorite. Accordingly, the Baba Ali profile, from the quartz syenite to the middle part of the exoskarn, demonstrates chiefly alkaline conditions of formation, with a gradual change to acidic towards the altered diorite host rocks. Utilising three parameters, $\mathrm{Ce} / \mathrm{Ce}^{*}, \mathrm{Eu} / \mathrm{Eu}^{*}$ and $(\mathrm{Pr} / \mathrm{Yb})_{\mathrm{n}^{\prime}}$ in different minerals implies that the hydrothermal fluids responsible for epidote and garnet were mostly of magmatic origin and for magnetite, actinolite and phlogopite these were of magmatic origin with low REE concentration or meteoric water involved.
\end{abstract}

Keywords: Almoughlagh, $\mathrm{Ce} / \mathrm{Ce}$ * ratio, $\mathrm{Eu} / \mathrm{Eu}^{*}$ ratio, $\mathrm{La} / \mathrm{Y}$ ratio

\section{Introduction}

Demonstrating the origin of hydrothermal fluids responsible for the formation of skarn deposits is one of the essential steps in the study of this type of deposits. The concentrations of rare earth elements (REEs) La to $\mathrm{Lu}$ in the hydrothermal fluids may yield useful data regarding the origin of ore-forming elements including base metals (Kato, 1999). REEs behave coherently during most geological processes due to similar chemical and physical properties (e.g., Taylor \& McLennan, 1985). In spite of this similarity, REEs can be fractionated during geochemical processes. Thus REE patterns normalised to standard material have been widely used as a tool to reveal various geochemical processes. However, it appears that there are few geochemical studies on REEs of skarn deposits (Kato, 1999).

The Baba Ali deposit is situated near the Almoughlagh Batholith, bounded between $48^{\circ} 10^{\prime} \mathrm{E}-48^{\circ} 15^{\prime} \mathrm{E}$ and $34^{\circ} 40^{\prime}-35^{\circ} 00^{\prime} \mathrm{N}$ in the western Sanandaj-Sirjan (S-S) Zone of Iran (Fig. 1A). The 
deposit is hosted by dioritic rocks and positioned at the contact border of the Almoughlagh quartz syenite and the Baba Ali diorite. More detailed general information on the Baba Ali deposit can be found in Amiri (1995) and Zamanian (2003). There are few studies of REE geochemistry in the Baba Ali deposit. Recent studies have focused on the geochemistry of the Almoughlagh Batholith and Baba Ali deposit (Zamanian \& Asadollahi, 2013). The present study considers distribution patterns of rare earth elements (REEs), which are a function of their geochemical behaviour, in alteration zones as well as in selected minerals. The relationship between REEs and the alteration index (A.I.) and $\mathrm{K}_{2} \mathrm{O}$ index and $\mathrm{pH}$ were specified as additional tools to determine the origin of the deposit according to the geochemical behaviour of REEs.

\section{Geological setting}

Structurally, the Baba Ali iron skarn deposit forms part of the Sanandaj-Sirjan (S-S) zone. There are three main rock units in the surrounding the Almoughlagh Batholith, namely the Songhor Series
(Triassic-Jurassic), the Hamadan Schists (Jurassic) and the Limy Formations (Oligo-Miocene) (Fig. 1B). The Songhor Series is a volcano-sedimentary sequence. This series consists of an alternation of schistose and limy units with interbedded metamorphosed spilitic volcanic rocks and andesitic tuff (Barud, 1975). The ratio volcanic rocks/sedimentary rocks is higher in the basal part of this sequence and decreases upwardly. The Songhor Series was affected by regional metamorphism and deformation during three successive orogenic phases, the Late Kimmerian ( 136 Ma; Amiri, 1995, Bellon \& Barud, 1975), the Laramide (65 Ma; Darvishzadeah, 1992) and the Pasadenian ( 2 Ma). The latter phase was accompanied by the emplacement of the Almoughlagh Batholith. In the Baba Ali magnetite skarn deposit, the main magnetite ore body is located between the dioritic and quartz syenitic rocks. In general, the Baba Ali area can be divided into two sections: volcanic-sedimentary and intrusive, the first section including the Songhor Series (Triassic-Jurassic) and the Limy Formations (Oligo-Miocene) and consists of quartzite, metarhyolite, garnet, micaschist, grey marble, metavolcanic and buff-colour marble unit.

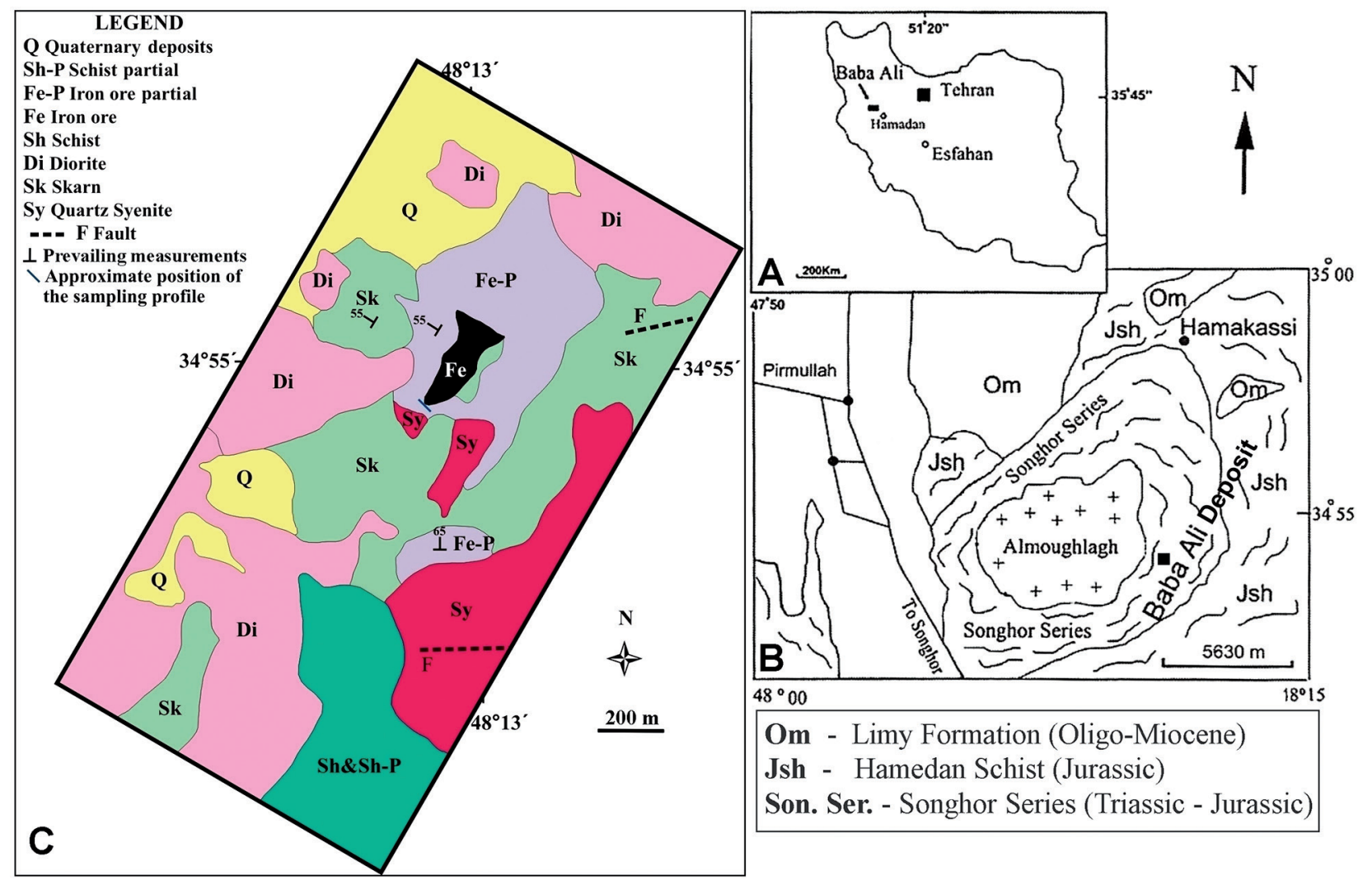

Fig. 1. A - Locality map of the Baba Ali region; B - Geological map of the Almoughlagh Batholith; C - Simplified geological map of the Baba Ali region. 


\subsection{Almoughlagh Batholith}

Petrologically the Almoughlagh Batholith is a complex body, constituted chiefly of quartz syenite and syenogranite groups (Fig. 1B). The quartz-syenites comprise quartz syenite to quartz alkali-syenites to alkali-syenite and quartz-monzonite. The syenogranite group grades from alkali-syenogranite, monzogranite to syenogranite (Table 1; Zamanian \& Asadollahi, 2013). Texturally, there is variation from fine-grained to pegmatitic in the syenogranites. Phenocrysts of K-feldspar occur in both the quartz syenite and

syenogranite that are mostly perthitic in syenites. Not only do such textures provide evidence of co-crystallisation, they also show the availability of water and other volatiles during crystallisation. In water-rich environments, K-feldspar and plagioclase have a greater tendency to form individual crystals, but with the escape of volatiles, they form a solid solution and eventually give rise to perthite. In extreme cases, with escaping volatiles, there is very little time for $\mathrm{K}$-feldspar and quartz to form individual and independent crystals. The predominance of magnetite over ilmenite, the low presence of chalcopyrite and association of sphene, green biotite and epidote (pistacite) indicate that the Almoughlagh quartz syenites and syenogranites belong to the 'Magnetite series' granitoids (Ishihara, 1981). Geochemical characteristics of the Almoughlagh granitoids demonstrate that the quartz syenite group is I-type, calc-alkaline and metaluminous, while the syenogranite group, although calc alkaline is partially peraluminous falling marginally into the S-type granitoid field (Zamanian, 2003). Small enclaves of Baba Ali metadiorite lie both within the Almoughlagh Batholith and along its margins. They demonstrate the unassimilated or unskarnised rocks which were subject to regional metamorphism along with the Songhor Series. Petrographically, these rocks show a relict igneous texture, are medium to coarse grained, consisting of phenocrysts of plagioclase (andesine to labradorite) within a groundmass of tiny plagioclase, quartz and hornblende. The phenocrysts show evidence of deformation such as bending, microfaulting and homogenisation of polysynthetic. The Baba Ali diorites were of I- type and the magma types maintained this sub-alkaline (particularly calc-alkaline) and chiefly metaluminous character. Different petrographical and geochemical characteristics of Almoughlagh Batholith and Baba Ali diorites, including QAP diagram, mineralogy petrographic variations and geochemical composition, were discussed by Zamanian \& Asadollahi (2013), to whom reference is made.

\subsection{Baba Ali skarn and ore body}

Skarn rocks are commonly classified on the basis of the predominant calc-silicates mineral assemblage into two types, viz. calcic and magnesian skarns. The presence of andradite, salite, actinolite, epidote, sphene and idocrase as calc-silicate minerals and the lack of minerals such as tremolite, forsterite, phlogopite, talc and humite allow to describe the Baba Ali skarn as a calcic Fe skarn deposit. Calcic Fe deposits are generally reported from skarns developed in meta-basic host rocks that are dioritic to gabbroic in composition (Einaudi et al., 1981). The Baba Ali deposit consists of several large and small lenses and veins showing a scattered pattern. Generally, the outcrops of the ores can be divided into

Table 1. Average mineral composition of the Almoughlagh granitoids (Zamanian, 2013).

\begin{tabular}{|c|c|c|c|c|c|c|c|c|c|}
\hline \multirow[b]{2}{*}{$\begin{array}{l}\text { Major } \\
\text { oxides }\end{array}$} & \multicolumn{5}{|c|}{ Quartz syenite group } & \multicolumn{4}{|c|}{ Syenogranite group } \\
\hline & $\begin{array}{l}\text { Quartz } \\
\text { syenite }\end{array}$ & $\begin{array}{l}\text { Quartz } \\
\text { mon- } \\
\text { zonite }\end{array}$ & $\begin{array}{c}\text { Alkali } \\
\text { syenite }\end{array}$ & $\begin{array}{l}\text { Quartz } \\
\text { alkali } \\
\text { syenite }\end{array}$ & Mean & $\begin{array}{l}\text { Alkali } \\
\text { syeno- } \\
\text { granite }\end{array}$ & $\begin{array}{l}\text { Syeno- } \\
\text { Granite }\end{array}$ & $\begin{array}{l}\text { Monzo- } \\
\text { granite }\end{array}$ & Mean \\
\hline $\mathrm{SiO}_{2}$ & 70.84 & 64.28 & 71.33 & 77.96 & 71.1 & 68.55 & 67.71 & 70.44 & 68.9 \\
\hline $\mathrm{Al}_{2} \mathrm{O}_{3}$ & 15.2 & 14.99 & 11.26 & 10.22 & 12.91 & 14.12 & 14.52 & 14.5 & 14.38 \\
\hline $\mathrm{TiO}_{2}$ & 0.41 & 1.11 & 0.35 & 0.05 & 0.48 & 0.06 & 0.58 & 0.62 & 0.42 \\
\hline $\mathrm{Fe}_{2} \mathrm{O}_{3}$ & 2.08 & 3.24 & 0.02 & 0.03 & 1.34 & 3.5 & 2.03 & 2.13 & 2.55 \\
\hline $\mathrm{FeO}$ & 1.14 & 1.94 & 0.48 & 0.40 & 0.24 & 1.34 & 1.50 & 1.34 & 1.39 \\
\hline $\mathrm{MgO}$ & 0.58 & 1.02 & 0.12 & 0.17 & 0.47 & 0.26 & 0.32 & 0.34 & 0.92 \\
\hline $\mathrm{CaO}$ & 0.1 & 4.94 & 0.74 & 0.64 & 1.67 & 2.12 & 3.29 & 3.8 & 3.07 \\
\hline $\mathrm{Na}_{2} \mathrm{O}$ & 4.69 & 3.53 & 2.34 & 1.45 & 3.02 & 5.33 & 5.90 & 3.77 & 5.0 \\
\hline $\mathrm{K}_{2} \mathrm{O}$ & 3.74 & 4.01 & 9.94 & 7.90 & 6.39 & 5.22 & 4.41 & 3.53 & 4.38 \\
\hline $\mathrm{MnO}$ & 0.02 & 0.08 & 0.01 & 0.03 & 0.03 & 0.06 & 0.02 & 0.01 & 0.03 \\
\hline $\mathrm{P}_{2} \mathrm{O}_{5}$ & 0.13 & 0.30 & 0.22 & 0.01 & 0.16 & 0.15 & 0.16 & 0.13 & 0.14 \\
\hline
\end{tabular}




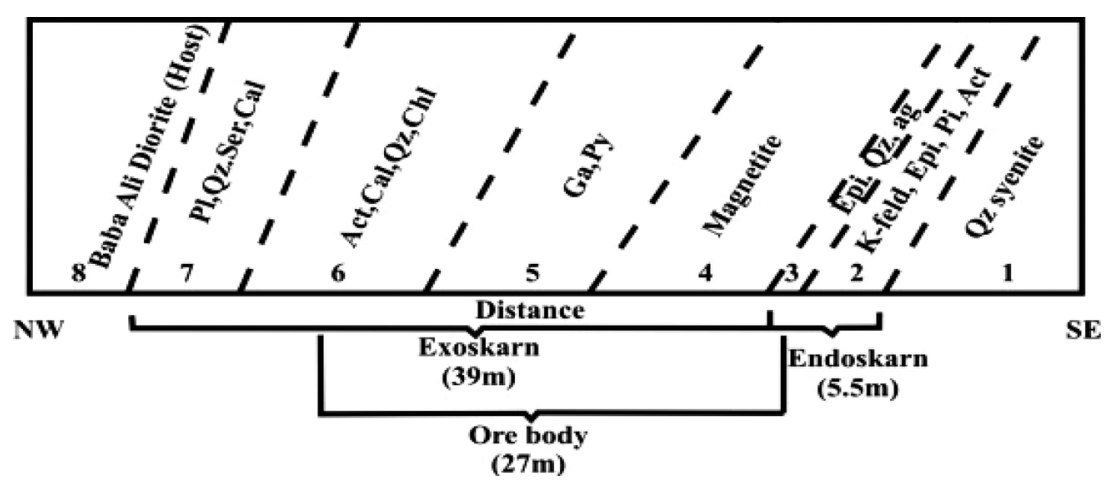

Fig. 2. The Baba Ali deposit with zones of endoskarn and exoskarn. The most important minerals in each zone are indicated.

three main groups: a) main body or central outcrop; b) a southwestern outcrop; c) a northern outcrops. The central outcrop, located in the northeast, is the main ore body. It shows an $\mathrm{N} 20^{\circ} \mathrm{E}$ trend, a length of about $250 \mathrm{~m}$ and a width of about $50 \mathrm{~m}$ (Fig. 1C). Magnetite is the main constituent of the ore bodies in the Baba Ali deposit. The estimated reserve for this is about $42 \mathrm{Mt}$ (Zamanian, 2003). The southwestern outcrop also includes several scattered and separated ore lenses and veins, which are parallel to each other and follow an E-W trend, dipping 60$65^{0}$ towards the north. They are mainly two veins, which are parallel to each other and situated 450 $\mathrm{m}$ to the south of the main ore body. These veins extend for about $110 \mathrm{~m}$ and show a width ranging from 5 to $7 \mathrm{~m}$. The estimated reserves for this part of the ore body are $23 \mathrm{Mt}$. The third and last group of the Baba Ali deposit consists of a number of lenses situated to the north of the main ore body. Their maximum length is about $40 \mathrm{~m}$ and a width of about 15 to $20 \mathrm{~m}$. The reserve of this lobe remains

Table 2. Average composition of the Baba Ali diorites (Zamanian, 2013).

\begin{tabular}{|c|c|c|c|c|c|}
\hline \multicolumn{6}{|c|}{ Baba Ali diorites } \\
\hline $\begin{array}{l}\text { Major } \\
\text { oxides }\end{array}$ & Diorite & $\begin{array}{l}\text { Monzo } \\
\text { diorite }\end{array}$ & $\begin{array}{l}\text { Quartz } \\
\text { Monzo } \\
\text { diorite }\end{array}$ & $\begin{array}{l}\text { Quartze } \\
\text { diorite }\end{array}$ & Mean \\
\hline $\mathrm{SiO}_{2}$ & 51.55 & 51.06 & 54.54 & 53.25 & 52.6 \\
\hline $\mathrm{Al}_{2} \mathrm{O}_{3}$ & 17.51 & 18.4 & 17.31 & 15.40 & 17.05 \\
\hline $\mathrm{Fe}_{2} \mathrm{O}_{3}$ & 3.27 & 3.29 & 3.75 & 6.51 & 4.36 \\
\hline $\mathrm{FeO}$ & 4.02 & 4.58 & 3.92 & 5.59 & 4.52 \\
\hline $\mathrm{MgO}$ & 5.3 & 6.33 & 4.47 & 5.30 & 5.35 \\
\hline $\mathrm{CaO}$ & 10.6 & 8.5 & 7.2 & 3.82 & 7.53 \\
\hline $\mathrm{Na}_{2} \mathrm{O}$ & 4.23 & 4 & 4.31 & 5.53 & 4.51 \\
\hline $\mathrm{K}_{2} \mathrm{O}$ & 0.4 & 1.25 & 0.8 & 0.35 & 0.7 \\
\hline $\mathrm{TiO}_{2}$ & 1.34 & 0.79 & 1.08 & 1.71 & 1.23 \\
\hline $\mathrm{MnO}$ & 0.015 & 0.18 & 0.15 & 0.09 & 0.1 \\
\hline $\mathrm{P}_{2} \mathrm{O}_{5}$ & 0.31 & 0.26 & 0.34 & 0.41 & 0.33 \\
\hline
\end{tabular}

unknown. Detailed field and microscopic examinations have indicated that the predominant ore minerals in the Baba Ali skarn are magnetite and hematite with minor malachite, pyrite and chalcopyrite. Gangue minerals mainly are calcite, quartz, chlorite, actinolite, phlogopite and epidote. Eight zones have been determined from the southeast to the northwest (from intrusion towards host rock of ore body; Zamanian \& Asadollahi, 2013). After quartz syenite, endoskarn, ore body, exoskarn and altered diorite follow respectively towards the northwest (Fig. 2). Samples were collected from a profile along an exploratory trench. The approximate position of the profile is shown on a simplified geological map of the Baba Ali deposit (Fig. 1C). Preliminary results obtained from a study of mineralogy and mineral types of each zone are as follows: Zone 1: quartzsyenite. This zone contains the quartz syenite of the Almoughlagh Batholith; the intrusion and emanations from these rocks thermally metamorphosed the metadiorite and led to skarnisation. The next zones are: Zone 2: altered quartz- syenite; Zone 3: epidote and quartz; Zone 4: ore zone; Zone 5: garnet, pyroxene; Zone 6: actinolite, calcite, quartz and chlorite; Zone 7: altered diorite zone. Zones 4, 5, 6 and 7 together form the exoskarn (Fig. 2). The exoskarn ( $39 \mathrm{~m}$ radius) in the Baba Ali deposit is much wider than the endoskarn (5.5 m radius); the ratio exoskarn/endoskarn being 7.0. The ore body, with a width of nearly $27 \mathrm{~m}$, is mostly within the exoskarn, but some mineralisation is also located in zones 2 and 3 within the endoskarn. The extensive exoskarn corroborates the role played by the dioritic host rock - it was comparable to any carbonate host rock that is usually known to form a geochemical barrier for precipitation of the metal content of ore-bearing fluids. Zone 8 is the main diorite zone. The average chemical composition of the Baba Ali diorites is listed in Table 2 (Zamanian \& Asadollahi, 2013). The occurrence of calcite as the only vein 
mineral and intersertal recrystallised grains is remarkable. Recent studies have demonstrated that diorite did not have any special relationship with the Almoughlagh syenite. The age of the diorite has been determined about $144 \pm 7$ million years. The diorite actually hosted skarn that became skarnised by hydrothermal fluids (Emami, 2000).

\section{Geochemistry of rare earth elements}

The study of REE behaviour in rocks and minerals is of note for the following reasons. First, REEs induced special behaviours during various geochemical processes which are why they are used as detectors in recognition of ores and rock origin as well as geological and tectonic settings. Secondly, environmental issues are highly significant to radioactive wastewater management and REEs are known as fissionable plutonium and uranium products in nuclear power plants (Brooking, 1984; Rard, 1988). Thirdly, economically speaking, they have several applications of extraordinary value. REEs are conveniently divided into three subgroups: HREE, MREE and LREE (Rollinson, 1993(. The fractionation degree between REEs can be determined by the LREE/HREE ratio. It has been pointed out that easy replacement of REEs by calcium as a result of isomorphic features with calcium is one of their significant features (Knarchenco \& Pokrovsky, 1995; Pollard, 1995).

\section{Sampling and laboratory methods}

In the present study different field samples were selected for different proposes. Fifteen samples from different parts of the mine were selected for XRF analysis at Tarbiat Moalem University and fifteen others were prepared for chemical analyses in the laboratories of ALS Chemex Canada. Quantitative values of major and minor elements, trace elements and REEs were measured by using inductively coupled plasma-atomic emission spectrometry and inductively coupled plasma-mass spectrometry analysing methods (ICP-MS). Laboratory work began with the preparation of thin and polished sections from all 55 samples and their examination under microscope. Locations of samples with the various lithounits of the Baba Ali deposit and their analytical values of major, minor, trace and rare earth elements are tabulated in Tables 3-7.

Table 3. Location of samples analysed.

\begin{tabular}{ccccc}
\hline Sample location & Altered Diorite & Skarn & Ore & Syenite Quartz \\
Sample No & A1-A2 & $\begin{array}{c}\text { A3-A4-A5-A6-A7 } \\
\text { A8-A9-A10-A11 }\end{array}$ & A12 & A13-A14-A15 \\
\hline
\end{tabular}

Table 4. Results of chemical analyses for rare earth elements in the Baba Ali deposit.

\begin{tabular}{lccccccccccccccc}
\hline Sample & A1 & A2 & A3 & A4 & A5 & A6 & A7 & A8 & A9 & A10 & A11 & A12 & A13 & A14 & A15 \\
& & & & & & & & & & & & & & \\
\hline La (ppm) & 38.2 & 48.3 & 12.9 & 24.6 & 17.6 & 25.5 & 36.9 & 31.4 & 154.5 & 115.5 & 135.5 & 10.4 & 39.2 & 86.7 & 43.2 \\
Ce & 76.2 & 73.1 & 38.5 & 67.9 & 49.8 & 53.8 & 76.3 & 78.7 & 233 & 167.6 & 202 & 16.6 & 81.3 & 135.5 & 94.6 \\
$\mathrm{Pr}$ & 8.81 & 7.34 & 5.35 & 9.13 & 6.42 & 6.42 & 8.88 & 9.78 & 22.3 & 15.8 & 19 & 1.29 & 9.14 & 12.3 & 10.95 \\
$\mathrm{Nd}$ & 35.2 & 27.8 & 23.9 & 38.9 & 27.3 & 27.1 & 34.9 & 39.4 & 76.1 & 54.4 & 64 & 4.5 & 35.7 & 39 & 43 \\
$\mathrm{Sm}$ & 7.29 & 6.79 & 5.44 & 8.31 & 6.23 & 6.7 & 7.55 & 8.88 & 14.1 & 10.35 & 11.3 & 0.67 & 7.56 & 7.4 & 9.44 \\
$\mathrm{Eu}$ & 1.98 & 2.92 & 2.12 & 2.95 & 2.28 & 2.16 & 2.08 & 2.12 & 4.22 & 4.56 & 3.46 & 0.07 & 2.32 & 2.64 & 2.06 \\
$\mathrm{Gd}$ & 7.39 & 7.62 & 5.62 & 8.2 & 6.12 & 6.64 & 7.73 & 8.85 & 15.1 & 11.15 & 11.85 & 0.83 & 7.45 & 7.86 & 9.37 \\
$\mathrm{~Tb}$ & 1.28 & 1.48 & 1.03 & 1.42 & 1.06 & 1.2 & 1.38 & 1.66 & 2.45 & 1.76 & 1.89 & 0.005 & 1.32 & 1.25 & 1.71 \\
$\mathrm{Dy}$ & 7.96 & 9.9 & 6.48 & 8.26 & 6.66 & 7.26 & 8.48 & 10.5 & 14.75 & 10.55 & 10.85 & 0.54 & 7.89 & 7.07 & 10.6 \\
$\mathrm{Ho}$ & 1.66 & 2.24 & 1.29 & 1.61 & 1.31 & 1.56 & 1.76 & 2.13 & 3.15 & 2.2 & 2.27 & 0.02 & 1.55 & 1.37 & 2.23 \\
$\mathrm{Er}$ & 4.91 & 6.84 & 3.69 & 4.63 & 3.76 & 4.26 & 5.25 & 6.3 & 9.16 & 6.26 & 5.57 & 0.23 & 4.63 & 3.96 & 6.57 \\
$\mathrm{Tm}$ & 0.76 & 1.15 & 0.55 & 0.67 & 0.57 & 0.63 & 0.83 & 1 & 1.37 & 0.95 & 0.94 & 0.02 & 0.7 & 0.56 & 1.09 \\
$\mathrm{Yb}$ & 4.64 & 7.38 & 3.21 & 3.76 & 3.34 & 3.78 & 4.8 & 5.96 & 8.12 & 5.43 & 5.88 & 0.22 & 4.42 & 3.45 & 6.21 \\
$\mathrm{Lu}$ & 0.7 & 1.17 & 0.47 & 0.54 & 0.47 & 0.52 & 0.73 & 0.9 & 1.25 & 0.82 & 0.88 & 0.005 & 0.64 & 0.47 & 0.96 \\
$\mathrm{Y}$ & 45.2 & 63.1 & 34.6 & 40.8 & 35.1 & 40 & 47.5 & 56.4 & 81.5 & 57.4 & 59.7 & 3.6 & 42.7 & 38.9 & 59.2 \\
\hline
\end{tabular}




\section{Discussion of results}

\subsection{Mobilisation, distribution and fractionation of REEs in the Baba Ali skarn lithounits}

Patterns of the chondrite-normalised REE for altered diorite, skarn, ore and quartz syenite show that, although the distribution pattern of REEs is more or less flat and smooth, in general LREEs show higher concentrations than HREEs in different lithounits (Fig. 3A-B). The chondrite-normalised values of the Baba Ali rocks are markedly variable, 28.9-376.4 for $\mathrm{La}$ and 0.9-32.7 for $\mathrm{Yb}$. This indicates that considerable differences of gain and loss occurred between LREEs and HREEs during the formation of the Baba Ali skarn rocks. The skarn zone shows the most enriched pattern, the ore zone the least enriched. A comparison of the concentration variations of light REEs (LREEs; La-Nd), middle REEs (MREEs; Sm-Ho) and heavy REEs (HREEs; $\mathrm{Er}-\mathrm{Lu}$ ) of the ore zone samples to the other zones elucidates two important points for the distribution of REEs (Fig. 4A-B).

The distribution patterns of LREEs and MREEs show a distinct depletion in the ore zone compared to the quartz syenite, altered diorite and exoskarn, yet represent a great enrichment in the skarn facies in close to the contact with the ore body and become lesser towards the altered diorite host rock.

HREEs show the same pattern, but in the exoskarn do not reveal a distinct increase compared to LREEs and MREEs. To evaluate the fractionation degree between REEs, various ratios of REEs such as $(\mathrm{La} / \mathrm{Yb})_{\mathrm{n}^{\prime}}(\mathrm{La} / \mathrm{Sm})_{\mathrm{n}}$ and $(\mathrm{Gd} / \mathrm{Yb})_{\mathrm{n}}$ were used. $(\mathrm{La} / \mathrm{Yb})_{\mathrm{n}}$ determines the degree of fractionation of LREEs from HREEs during geochemical processes (Aubert et al., 2001; Yusoff et al., 2013), while the two other ratios establish the degree of fractionation

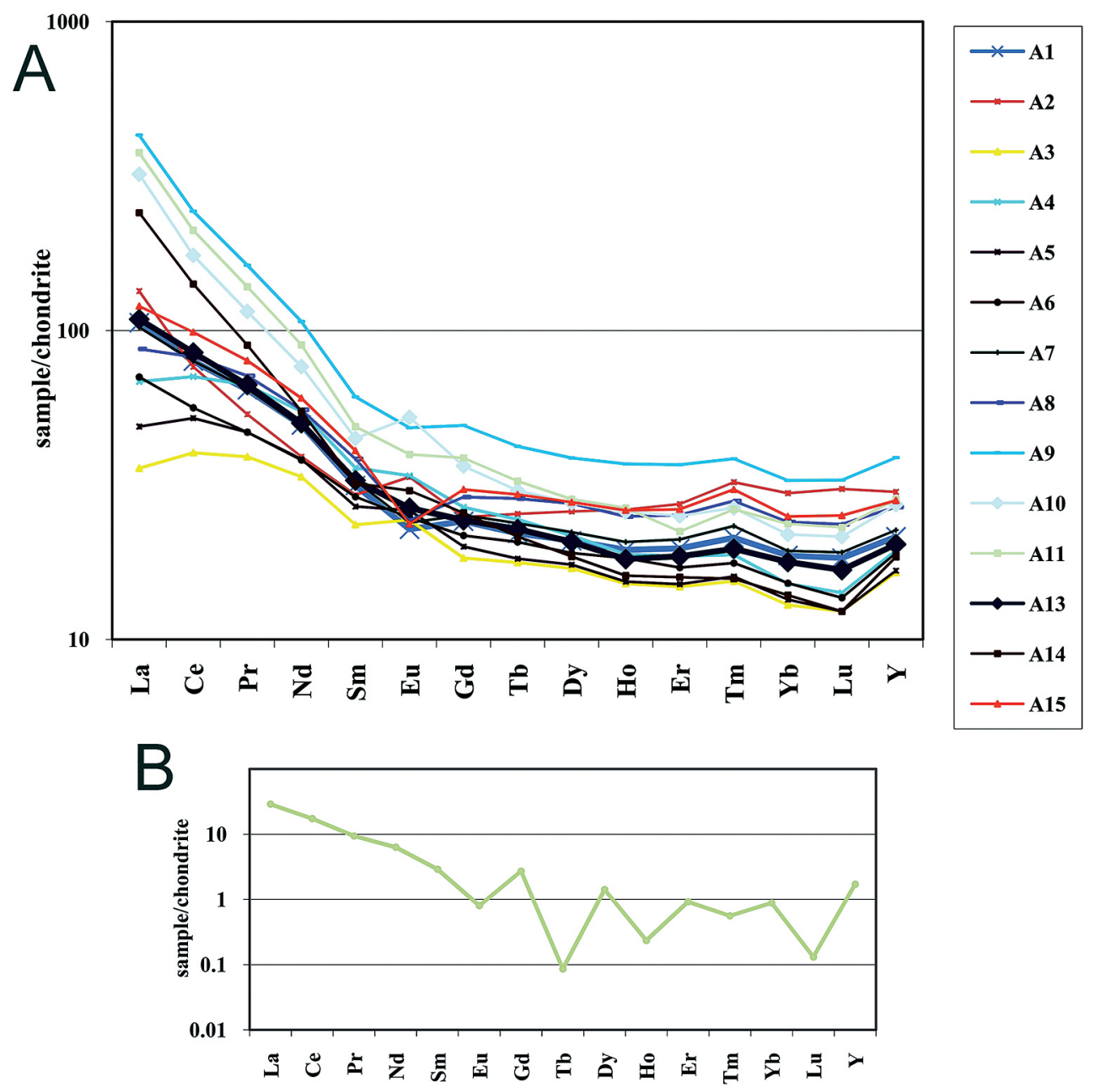

Fig. 3. Chondrite-normalised REE patterns (by Taylor \& McLennan, 1985) of samples from the Baba Ali deposit. A A1-A11 and A13-A15; B - A12. 

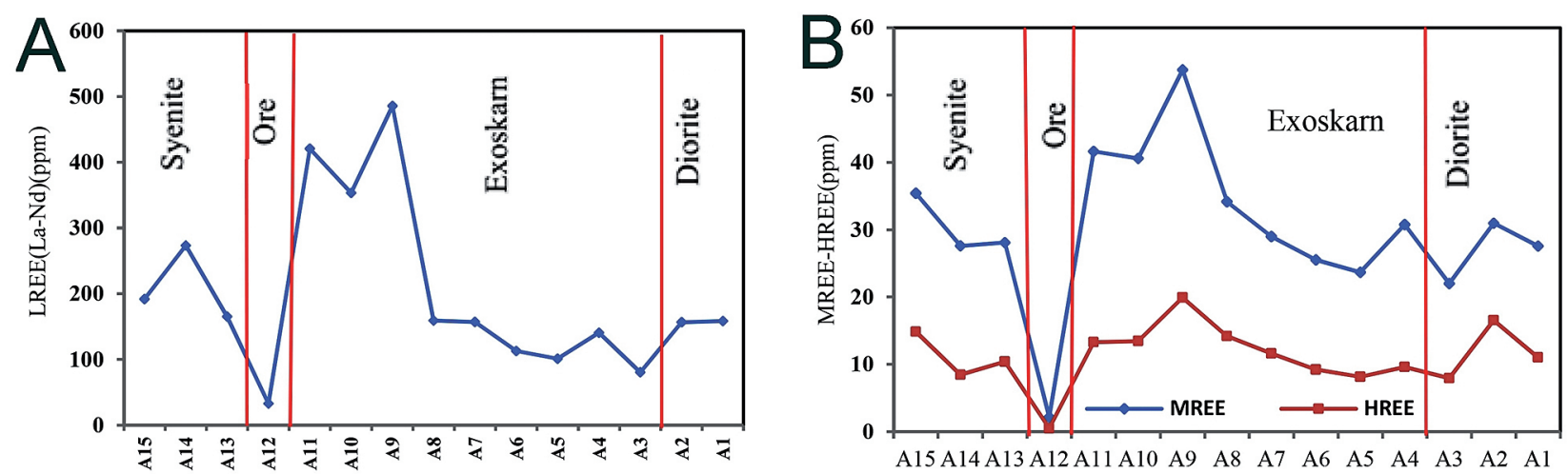

Fig. 4. Concentration variations of: A - LREEs (La-Nd(; B - MREEs(Sm-Ho(, HREEs (Er-Lu).

between LREEs and MREEs and between MREEs and HREEs, respectively (Yusoff et al., 2013).

The values of these ratios have ranges for $(\mathrm{La} /$ $\mathrm{Yb})_{\mathrm{n}}$ from 2.8 to 32.6 for $(\mathrm{La} / \mathrm{Sm})_{\mathrm{n}}$ from 1.52 to 10 and for $(\mathrm{Gd} / \mathrm{Yb})_{\mathrm{n}}$ from 0.8 to 3.1 (Table 5). The greatest fractionation occurred between LREEs and HREEs (up to 32 times) and a relatively minor fractionation between MREEs and HREE during skarnization processes. These ratios reflect fractionations as follows: LREEE/HREE > LREE/MREE> MREE/HREE (Fig. 5A). The highest values of the three ratios have been observed in the ore zone $(\mathrm{La} / \mathrm{Yb})_{\mathrm{n}}=32.6(\mathrm{La} / \mathrm{Sm})_{\mathrm{n}}=10$ and $(\mathrm{Gd} / \mathrm{Yb})_{\mathrm{n}}=3.1$ (Table 5) that represent high fractionation of REE in the ore zone not only because of low HREE but also on account of low MREE and HREE. Since the distribution pattern of REEs is governed by mainly geochemical conditions, the La/Y ratios render useful data for determination of $\mathrm{pH}$ in the environment of ore formation. Values of La/Y $>1$ show alkaline conditions, while value of $\mathrm{La} / \mathrm{Y}<1$ indicate acidic conditions (Crinci \& Jurkowic, 1990). This ratio at the Baba Ali skarn ranges from 0.37 to 2.89 (Table 5). The ore zone has the highest La/Y values (2.89). In this regard the skarn zones exhibit two distinctive parts: 1 ) a part that has $\mathrm{La} / \mathrm{Y}>1$ which is adjacent to the ore body and; 2) a portion with La/Y $<1$ which borders diorite. These divisions indicate basic and acidic conditions of hydrothermal alteration during skarnisation, respectively (Fig. 5B). Accordingly, the Baba Ali profile from the quartz syenite to the middle part of the exoskarn (location sample 8) show chiefly alkaline conditions of formation; from there it gradually changed to acidic towards the altered diorite host rock. Therefore, we can expect that in a hydrothermally affected environment where the hot and acidic REE-bearing solutions had been diluted through completed interaction with carbonate veins of diorite, alkaline $\mathrm{pH}$ values had been achieved. This leads to enrichment in concentration of REEs mainly in the southeast part of the exoskarn zones. Unlike this, interaction in the northwest part of the exoskarn was not completed as remnants of carbonate veins are available, the acidic nature of primary solution having been retained. Thus, REEs are leached from the acidic parts and then deposited (due to the buffering of

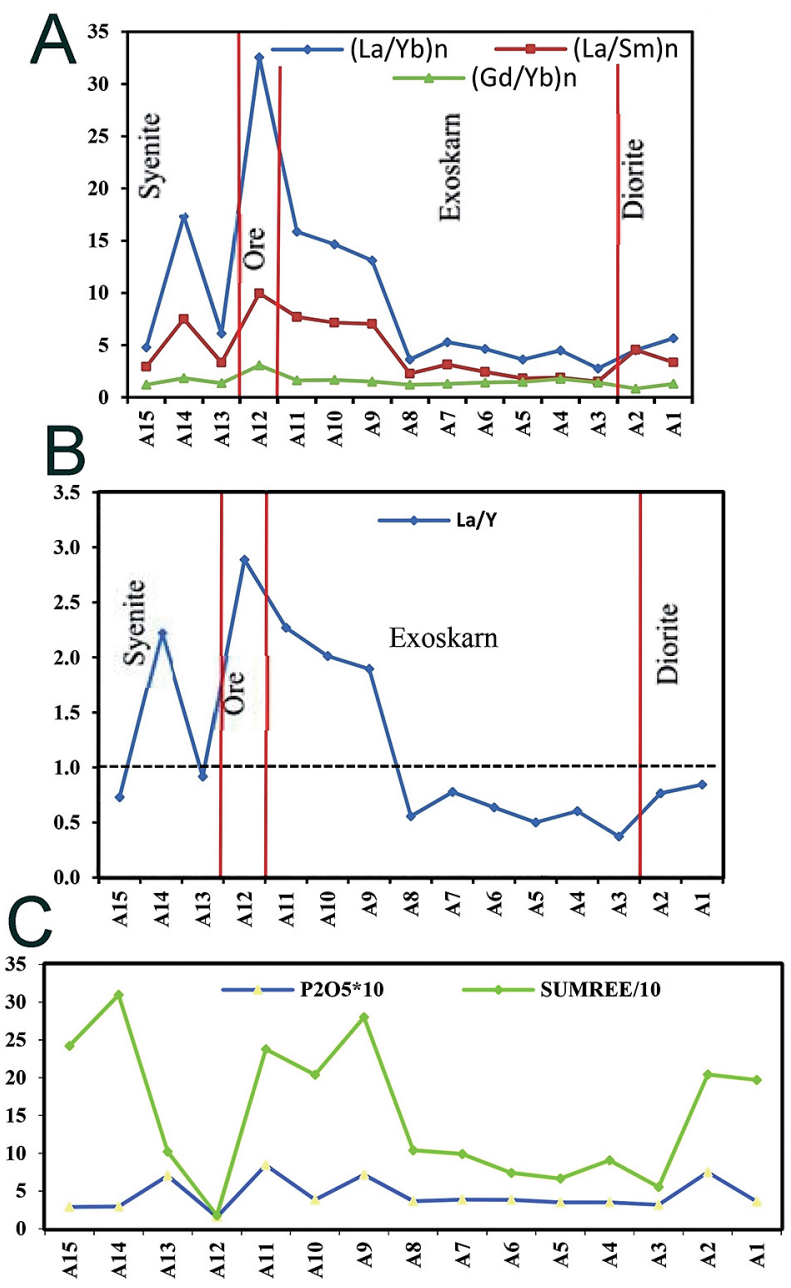

Fig. 5. Variations of: $\mathbf{A}-(\mathrm{La} / \mathrm{Yb})_{\mathfrak{n}^{\prime}}(\mathrm{La} / \mathrm{Sm})_{n}$ and $(\mathrm{Gd} / \mathrm{Yb})_{n}$ values; $\mathbf{B}$ - La/Y values; $\mathbf{C}$ - diagram illustrating the positive correlation between REEs and $\mathrm{P}_{2} \mathrm{O}_{5}$. 
Table 5. Values of LREE (La-Nd), MREE (Sm-Ho), HREE (Er-Lu), SREE (La-Lu), (La/Lu) $)_{n^{\prime}} \mathrm{La} / \mathrm{Y}, \mathrm{Eu} / \mathrm{Eu}^{*}, \mathrm{Ce} / \mathrm{Ce}$, $(\mathrm{La} /$ $\mathrm{Sm})_{\mathrm{n}^{\prime}}(\mathrm{La} / \mathrm{Yb})_{\mathrm{n}^{\prime}}(\mathrm{Gd} / \mathrm{Yb})_{\mathrm{n}^{\prime}}(\mathrm{Pr} / \mathrm{Yb})_{\mathrm{n}^{\prime}}$, A.I. and K.I.

\begin{tabular}{|c|c|c|c|c|c|c|c|c|}
\hline Sample & A1 & A2 & A3 & A4 & A5 & A6 & A7 & A8 \\
\hline LREELa-Nd ppm & 158.41 & 156.54 & 80.65 & 140.53 & 101.12 & 112.82 & 156.98 & 159.28 \\
\hline MREESm-Ho ppm & 27.56 & 30.95 & 21.98 & 30.75 & 23.66 & 25.52 & 28.98 & 34.14 \\
\hline HREEEr-Lu ppm & 11.01 & 16.54 & 7.92 & 9.60 & 8.14 & 9.19 & 11.61 & 14.16 \\
\hline$\Sigma$ REE - (La-Lu)ppm & 196.98 & 204.03 & 110.55 & 180.88 & 132.92 & 147.53 & 197.57 & 207.58 \\
\hline$(\mathrm{La} / \mathrm{Lu})_{\mathrm{n}}$ & 5.78 & 4.37 & 2.90 & 4.82 & 3.96 & 5.19 & 5.35 & 3.69 \\
\hline $\mathrm{La} / \mathrm{Y}$ & 0.85 & 0.77 & 0.37 & 0.60 & 0.50 & 0.64 & 0.78 & 0.56 \\
\hline $\mathrm{Eu} / \mathrm{Eu}^{*}$ & 0.82 & 1.24 & 1.16 & 1.08 & 1.12 & 0.98 & 0.83 & 0.72 \\
\hline $\mathrm{Ce} / \mathrm{Ce}^{*}$ & 0.93 & 0.81 & 1.07 & 1.05 & 1.09 & 0.96 & 0.95 & 1.04 \\
\hline$(\mathrm{La} / \mathrm{Sm})_{\mathrm{n}}$ & 3.36 & 4.56 & 1.52 & 1.90 & 1.81 & 2.44 & 3.14 & 2.27 \\
\hline$(\mathrm{La} / \mathrm{Yb})_{\mathrm{n}}$ & 5.67 & 4.51 & 2.77 & 4.51 & 3.63 & 4.65 & 5.30 & 3.63 \\
\hline$(\mathrm{Gd} / \mathrm{Yb})_{\mathrm{n}}$ & 1.29 & 0.84 & 1.42 & 1.77 & 1.49 & 1.42 & 1.31 & 1.20 \\
\hline$(\operatorname{Pr} / Y b)_{n}$ & 3.44 & 1.80 & 3.02 & 4.40 & 3.48 & 3.07 & 3.35 & 2.97 \\
\hline A.I & 19.23 & 6.06 & 29.60 & 29.63 & 31.69 & 32.09 & 33.35 & 28.23 \\
\hline K.I & 8.00 & 0.12 & 6.57 & 5.06 & 4.92 & 6.43 & 8.70 & 9.23 \\
\hline Sample & A9 & A10 & A11 & A12 & A13 & A14 & A15 & \\
\hline LREELa-Nd ppm & 485.90 & 353.30 & 420.50 & 32.79 & 165.34 & 273.50 & 191.75 & \\
\hline MREESm-Ho ppm & 53.77 & 40.57 & 41.62 & 2.14 & 28.09 & 27.59 & 35.41 & \\
\hline HREEEr-Lu ppm & 19.90 & 13.46 & 13.27 & 0.48 & 10.39 & 8.44 & 14.83 & \\
\hline$\Sigma \mathrm{REE}-(\mathrm{La}-\mathrm{Lu}) \mathrm{ppm}$ & 559.57 & 407.33 & 475.39 & 35.4 & 203.82 & 309.53 & 241.99 & \\
\hline$(\mathrm{La} / \mathrm{Lu})_{\mathrm{n}}$ & 13.08 & 14.91 & 16.30 & 220.13 & 6.48 & 19.52 & 4.76 & \\
\hline $\mathrm{La} / \mathrm{Y}$ & 1.90 & 2.01 & 2.27 & 2.89 & 0.92 & 2.23 & 0.73 & \\
\hline $\mathrm{Eu} / \mathrm{Eu}^{*}$ & 0.88 & 1.29 & 0.91 & 0.29 & 0.93 & 1.05 & 0.66 & \\
\hline $\mathrm{Ce} / \mathrm{Ce}^{*}$ & 0.82 & 0.80 & 0.82 & 0.91 & 0.97 & 0.86 & 0.99 & \\
\hline$(\mathrm{La} / \mathrm{Sm})_{\mathrm{n}}$ & 7.03 & 7.16 & 7.69 & 9.96 & 3.33 & 7.52 & 2.94 & \\
\hline$(\mathrm{La} / \mathrm{Yb})_{\mathrm{n}}$ & 13.11 & 14.65 & 15.87 & 32.57 & 6.11 & 17.31 & 4.79 & \\
\hline$(\mathrm{Gd} / \mathrm{Yb})_{\mathrm{n}}$ & 1.51 & 1.66 & 1.63 & 3.06 & 1.37 & 1.85 & 1.22 & \\
\hline$(\mathrm{Pr} / \mathrm{Yb})_{\mathrm{n}}$ & 4.97 & 5.27 & 5.85 & 10.61 & 3.74 & 6.45 & 3.19 & \\
\hline A.I & 21.76 & 25.97 & 22.63 & 1.45 & 18.71 & 24.35 & 36.84 & \\
\hline K.I & 5.61 & 2.23 & 7.31 & 1.45 & 1.92 & 2.54 & 26.57 & \\
\hline
\end{tabular}

solutions by carbonate veins) in the basic parts. In spite of elevated basic conditions the lowest REEs concentrations are seen in the ore zone. This is due to mineral paragenesis which consists mainly of magnetite that could not fix or concentrate REE in its structure. Unlike apatite and titanomagnetite, pure magnetite is not a suitable centraliser for REE (Asadi, 2009). EPMa (Electron Probe Microanalyser) analysis of magnetite from the Baba Ali deposit shows a rather pure magnetite phase and we cannot see impurities such as $\mathrm{Mg}, \mathrm{Mn}, \mathrm{Zn}, \mathrm{Ni}, \mathrm{Ti}, \mathrm{V}$ and $\mathrm{Cr}$ (Zamanian, 2003). Lower REE concentration in the ore zone could be due to the purity of the magnetite phase. As the shear zones formed under relatively similar PT conditions, it is likely that the stability of the REE- bearing minerals is controlled by the fluid, i.e., $\mathrm{pH}$, oxygen fugacity $\left(\mathrm{fO}_{2}\right)$ and concentrations of potential REE ligands $\left(\mathrm{SO}_{4}^{-2}, \mathrm{CO}_{3}^{-2}, \mathrm{OH}^{-}, \mathrm{F}^{-}\right.$, $\left.\mathrm{PO}_{4}^{-2}\right)$. These REE ligands may precipitate into REE minerals or REE- bearing minerals in response to changes in fluid composition, because of fractional crystallisation, fluid-rock reaction, or fluid-mixing processes (Rolland et al., 2003). Precipitation and dissolution of various REE minerals at different stages of shear zone genesis illustrate that changes in fluid chemistry occurred in individual shear zones (Rolland et al., 2003). One of the most susceptible minerals for concentration REE is apatite. In this regard, a close relationship is seen between phosphor and $\sum$ REEs in different lithounits of the Baba Ali (Fig. 5C).

\subsection{Controlling factors of $\mathrm{Ce}$ and $\mathrm{Eu}$ anomalies}

Calculations of Eu and $\mathrm{Ce}$ anomalies are defined by the following equations (Taylor \& McLennan, 1985): $\mathrm{Ce} / \mathrm{Ce}^{*}=(2 \mathrm{Ce} / \mathrm{Ce}$ chondrite $) /(\mathrm{La} / \mathrm{La}$ chondrite $+\operatorname{Pr} / \operatorname{Pr}$ chondrite $)$ and $\mathrm{Eu} / \mathrm{Eu}^{*}=(2 \mathrm{Eu} /$ Eu chondrite)/ (Sm/Sm chondrite + Gd/Gd chondrite). The Eu and Ce anomaly values across the 
Baba Ali lithounits range from 0.29-1.24 and 0.81.09, respectively (Table 5; Fig. 6A-B). Values $>1$ and $<1$ are called positive and negative anomalies, respectively. Plotting the $\mathrm{Ce} / \mathrm{Ce}^{*}$ values of exoskarn samples on a $\mathrm{Ce} / \mathrm{Ce}^{*}$ vs $\sum \mathrm{REEs}$ binary diagram represents two populations including anomalies: 1) lower than 1 belonging to the part adjacent to the ore zone and; 2) more than 1 which belongs to a part of the exoskarn adjacent to the altered diorite host rocks. This situation also is repeated for $\mathrm{Eu} /$ $\mathrm{Eu}^{*}$ (Fig. 6B). The skarn zone, on the basis of REE values and $\mathrm{Ce}$ anomalies, can be divided into two distinct parts: 1) one indicating acidic conditions as well as showing positive Ce anomalies with low values of REE (actually a leached zone) and field; 2) one with an alkaline $\mathrm{pH}$, negative $\mathrm{Ce}$ anomalies and high REE values. This is in fact an enrichment zone. The positive anomalies of $\mathrm{Ce}$ indicate that $\mathrm{Ce}$ was fixed as $\mathrm{Ce}^{4+}$ under acidic and oxidising conditions. The only logical and acceptable factor for the negative anomalies for Ce in the skarn zone is the coupled complexation of $\mathrm{Ce}^{4+}$ with carbonate ligands and its leaching during the skarnisation processes (Karadag et al., 2009).

Since the Eu carriers are plagioclases, it might be related to the degree of plagioclase alteration. An Eu positive anomaly strongly indicates early stages of rock alteration in acidic environments (Kikawa$\mathrm{da}, 2001)$. The positive anomalies of $\mathrm{Eu}$ and (La/ $\mathrm{Lu})_{\mathrm{n}}$ represent acidic fluids of high temperature (Wood, 1990). Considering the three parameters $\mathrm{Ce} / \mathrm{Ce}^{*}, \mathrm{Eu} / \mathrm{Eu}^{*}$ and $(\mathrm{Pr} / \mathrm{Yb})_{\mathrm{cn}}$ in the skarn zone show that at least two different type of hydrothermal fluids affected the diorite host rock: 1) low REE concentration fluid with mainly positive $\mathrm{Ce}$ and $\mathrm{Eu}$ anomalies denoting the acidic and oxidising nature of the hydrothermal fluids and 2) high REE concentration fluid with negative anomalies of $\mathrm{Eu}$ and $\mathrm{Ce}$ indicating alkaline and redox conditions of such fluids (Fig. 7A-C). The presence of pestacite and the high exoskarn/endoskarn ratio (extensive

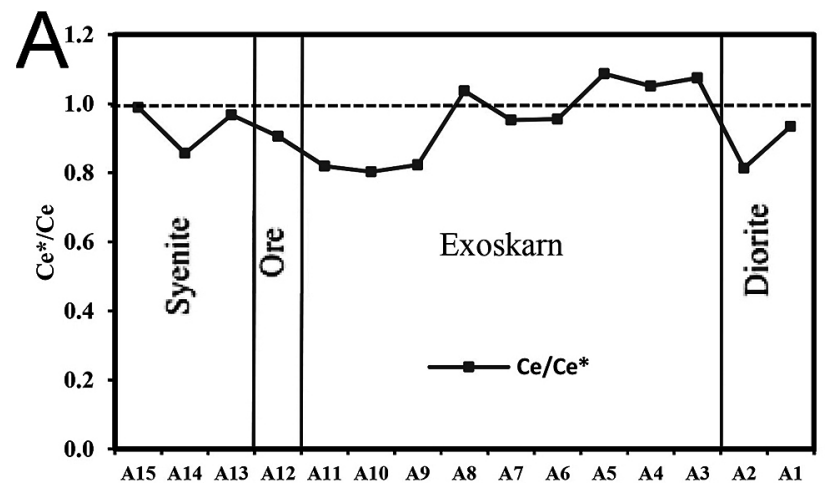

Fig. 6. Variations of: $\mathbf{A}-\mathrm{Ce} / \mathrm{Ce}^{*} ; \mathbf{B}-\mathrm{Eu} / \mathrm{Eu}^{*}$ values. exoskarn facies) show a shallow depth 'hypabyssal' $(<5 \mathrm{~km})$ and high activity of oxygen (oxidisation condition) for the formation of the Baba Ali skarn (Zamanian, 2003). The positive anomalies of $\mathrm{Eu}$ in A2-A3-A4-A5-A10-A14 are linked to modal plagioclase in their mineralogy which is also confirmed by microscopic observations. The largest negative Eu anomaly exists in the ore zone which is caused by a lack of alteration products in this zone. There is a good and positive correlation between $\mathrm{Eu} / \mathrm{Eu}^{*}$ and $\mathrm{CaO}$, which resulted in $\mathrm{CaO}$ replacement by $\mathrm{Eu}$ (Fig. 7D). Previous studies have shown that the chemical composition $\left(\mathrm{K}_{2} \mathrm{O}, \mathrm{Na}_{2} \mathrm{O}, \mathrm{CaO}, \mathrm{MgO}\right)$ and oxygen isotopic composition $(\delta 18 \mathrm{O})$ of hydrothermally altered rocks vary systematically with distance from the ore body and thus provide a useful geochemical index for exploration (e.g., Green et al., 1983; Hashiguchi et al.,1983).

Amongst the geochemical exploration indexes, the $\mathrm{K}_{2} \mathrm{O}$ index: K.I. $=\mathrm{K}_{2} \mathrm{O} /\left(\mathrm{Na}_{2} \mathrm{O}+\mathrm{K}_{2} \mathrm{O}+\mathrm{CaO}+\right.$ $\mathrm{MgO}) \times 100)$ and the alteration index: A.I. $=(\mathrm{MgO}+$ $\left.\mathrm{K}_{2} \mathrm{O}\right) /\left(\mathrm{Na}_{2} \mathrm{O}+\mathrm{K}_{2} \mathrm{O}+\mathrm{CaO}+\mathrm{MgO}\right) \times 100$ (Ishikawa et al., 1976) are frequently used. Another geochemical usage of REEs relates to the binary discriminative diagram in which $\sum$ REEs are potted $v$ s K.I and A.I. Plotting these two parameters against REEs helps describe the hydrothermal nature and their influence on the metasomatosed rocks. The values of those two ratios across the Baba Ali lithounits range for A.I. from 1.45 to 36.8 and for K.I. from 1.45 to 26.57 , respectively (Tables 5-6). A positive correlation is observed between $\mathrm{Eu} / \mathrm{Eu}^{*}$ and alteration index (A.I.) in skarn rocks adjacent to the quartz syenite becoming weak towards the altered diorite (Table 5). The negative $\mathrm{Eu}$ anomaly in the ore zone results from the purity of magnetite in this zone. Unlike apatite and titanomagnetite, pure magnetites are not suitable centralisers for REE (Asadi, 2009).

Relationships between K.I. and A.I. with HREE, LREE, $(\mathrm{La} / \mathrm{Sm})_{\mathrm{n}^{\prime}}(\mathrm{La} / \mathrm{Yb})_{\mathrm{n}}$ and $\mathrm{Eu} / \mathrm{Eu}^{*}$ in the Baba

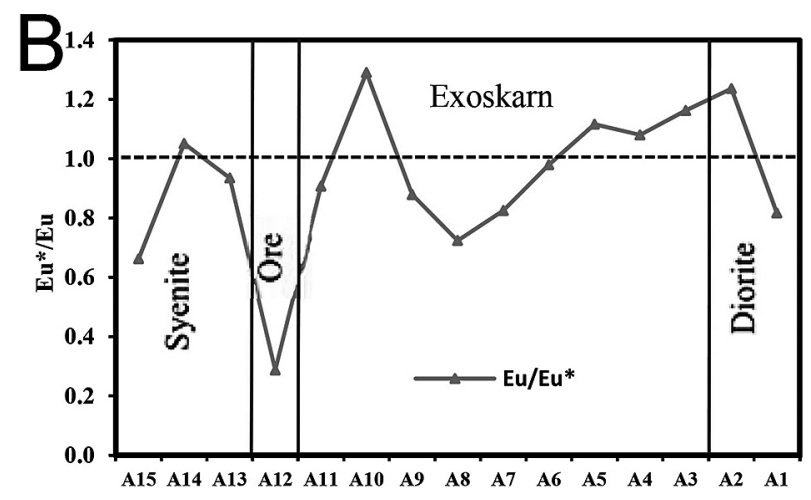



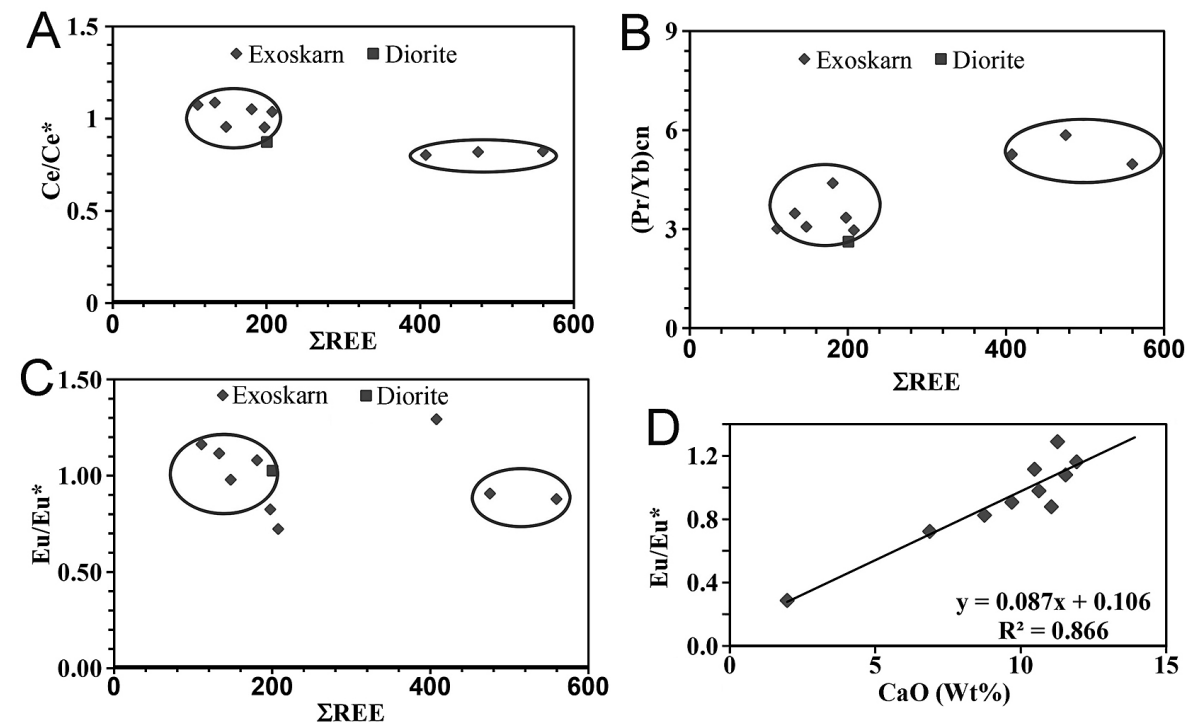

Fig. 7. A - Relationship between Ce/Ce* - vs $\sum \mathrm{REE}$; $\mathbf{B}-(\mathrm{Pr} / \mathrm{Yb})_{\mathrm{cn}}$ vs $\sum \mathrm{REE} ; \mathbf{C}-\mathrm{Eu} / \mathrm{Eu}^{*}$ vs $\sum \mathrm{REE}$ in skarn zone and diorite; D - diagram featuring the positive correlation between $\mathrm{Eu} / \mathrm{Eu}^{*}$ and $\mathrm{CaO}$.

Table 6. Results of chemical analyses for major elements in the Baba Ali deposit.

\begin{tabular}{|c|c|c|c|c|c|c|c|c|}
\hline \multirow{2}{*}{ Sample } & \multicolumn{8}{|c|}{ Oxides \% } \\
\hline & $\mathrm{SiO}_{2}$ & $\mathrm{Al}_{2} \mathrm{O}_{3}$ & $\mathrm{Fe}_{2} \mathrm{O}_{3}$ & $\mathrm{MgO}$ & $\mathrm{MnO}$ & $\mathrm{CaO}$ & $\mathrm{Na}_{2} \mathrm{O}$ & $\mathrm{K}_{2} \mathrm{O}$ \\
\hline A1 & 60.3 & 14 & 6.69 & 1.84 & 0.1 & 6.63 & 6.6 & 1.31 \\
\hline $\mathrm{A} 2$ & 38.3 & 5.9 & 18 & 2 & 0.39 & 31.4 & 0.27 & 0.04 \\
\hline A3 & 52.8 & 13.3 & 7.75 & 4.94 & 0.12 & 11.9 & 3.18 & 1.41 \\
\hline A4 & 52 & 13.9 & 6.81 & 5.29 & 0.11 & 11.5 & 3.61 & 1.09 \\
\hline A5 & 53.6 & 13 & 6.84 & 5.44 & 0.1 & 10.5 & 3.41 & 1 \\
\hline A6 & 53.1 & 12.7 & 7 & 5.23 & 0.1 & 10.6 & 3.22 & 1.31 \\
\hline A7 & 52.4 & 13.4 & 8.67 & 4.45 & 0.11 & 8.75 & 3.28 & 1.57 \\
\hline A8 & 58.3 & 12 & 6.83 & 3.15 & 0.1 & 6.87 & 5.03 & 1.53 \\
\hline A9 & 50.7 & 13.2 & 9.19 & 3.05 & 0.14 & 11.1 & 3.73 & 1.06 \\
\hline A10 & 53.4 & 11.2 & 8.29 & 4.89 & 0.15 & 11.3 & 3.99 & 0.46 \\
\hline A11 & 54 & 10.8 & 12.2 & 2.64 & 0.16 & 9.69 & 3.64 & 1.26 \\
\hline A12 & 9.38 & 7.48 & 74.5 & 0 & 0.05 & 1.97 & 0.07 & 0.03 \\
\hline A13 & 56.2 & 12.2 & 8.66 & 2.88 & 0.11 & 8.16 & 5.79 & 0.33 \\
\hline A14 & 50.5 & 11.8 & 13.5 & 4.63 & 0.18 & 13.4 & 2.69 & 0.54 \\
\hline A15 & 62.4 & 13.1 & 5.5 & 1.68 & 0.1 & 5.85 & 4.49 & 4.35 \\
\hline \multirow{2}{*}{ Sample } & \multicolumn{4}{|c|}{ Oxides \% } & \multirow{2}{*}{ Total } & \multirow{2}{*}{ K.I } & \multirow{2}{*}{ A.I } & \\
\hline & $\mathrm{TiO}_{2}$ & $\mathrm{P}_{2} \mathrm{O}_{5}$ & $\mathrm{P}_{2} \mathrm{O}_{5} * 10$ & $\mathrm{SO}_{3}$ & & & & \\
\hline A1 & 1.4 & 0.36 & 3.59 & 0.01 & 99.3 & 8 & 19.2 & \\
\hline A2 & 0.35 & 0.75 & 7.47 & 0.01 & 97.4 & 0.12 & 6.06 & \\
\hline A3 & 1.46 & 0.32 & 3.16 & 0.02 & 97.2 & 6.57 & 29.6 & \\
\hline A4 & 1.64 & 0.35 & 3.48 & 0.01 & 96.3 & 5.06 & 29.6 & \\
\hline A5 & 1.57 & 0.35 & 3.49 & 0.01 & 95.8 & 4.92 & 31.7 & \\
\hline A6 & 1.59 & 0.38 & 3.82 & 0.01 & 95.2 & 6.43 & 32.1 & \\
\hline A7 & 1.64 & 0.39 & 3.85 & 0.01 & 94.7 & 8.7 & 33.4 & \\
\hline A8 & 1.59 & 0.37 & 3.65 & 0.01 & 95.8 & 9.23 & 28.2 & \\
\hline A9 & 1.71 & 0.72 & 7.15 & 0.01 & 94.5 & 5.61 & 21.8 & \\
\hline A10 & 1.55 & 0.38 & 3.83 & 0.01 & 95.5 & 2.23 & 26 & \\
\hline A11 & 1.85 & 0.84 & 8.41 & 0.01 & 97.1 & 7.31 & 22.6 & \\
\hline A12 & 0.1 & 0.16 & 1.56 & 7.14 & 101 & 1.45 & 1.45 & \\
\hline A13 & 1.7 & 0.7 & 7.01 & 0.03 & 96.8 & 1.92 & 18.7 & \\
\hline A14 & 1.06 & 0.29 & 2.94 & 0.04 & 98.6 & 2.54 & 24.4 & \\
\hline A15 & 1.14 & 0.29 & 2.87 & 0.01 & 98.9 & 26.6 & 36.8 & \\
\hline
\end{tabular}


Ali deposit (Figs. 8-9) indicates that the correlation between K.I. and A.I. with HREE, LREE, $(\mathrm{La} / \mathrm{Sm})_{n^{\prime}}(\mathrm{La} /$ $\mathrm{Yb})_{\mathrm{n}}$ and $\mathrm{Eu} / \mathrm{Eu}^{*}$ is not clear for the altered diorite zone. Diorite is far from quartz syenite and this weak correlation points to the lesser role of diorite for concentration of REEs from hydrothermal fluids. The relationships between K.I. and A.I. with HREE, LREE, $(\mathrm{La} / \mathrm{Sm})_{n^{\prime}}(\mathrm{La} / \mathrm{Yb})_{\mathrm{n}}$ are not clear for the skarn zone samples.

There is a positive correlation between K.I. and A.I. with LREE, $(\mathrm{La} / \mathrm{Sm})_{\mathrm{n}^{\prime}}(\mathrm{La} / \mathrm{Yb})_{\mathrm{n}^{\prime}} \mathrm{Eu} / \mathrm{Eu}^{*}$ in the quartz syenite zone. This suggests that the hydrothermal fluids responsible for alteration of quartz syenite had very high REE, $(\mathrm{La} / \mathrm{Sm})_{\mathrm{n}^{\prime}}(\mathrm{La} / \mathrm{Yb})_{\mathrm{n}^{\prime}} \mathrm{Eu} /$ $\mathrm{Eu}$ ratios to the quartz syenite. These signatures indicate that the hydrothermal fluids responsible for the alteration and skarnisation of the Baba Ali were mostly of magmatic origin. The negative correlation between K.I. and A.I. with HREE indicates that the fluids had low HREE.

For further studies samples of epidote (from the endoskarn), magnetite (from the ore zone) gar-
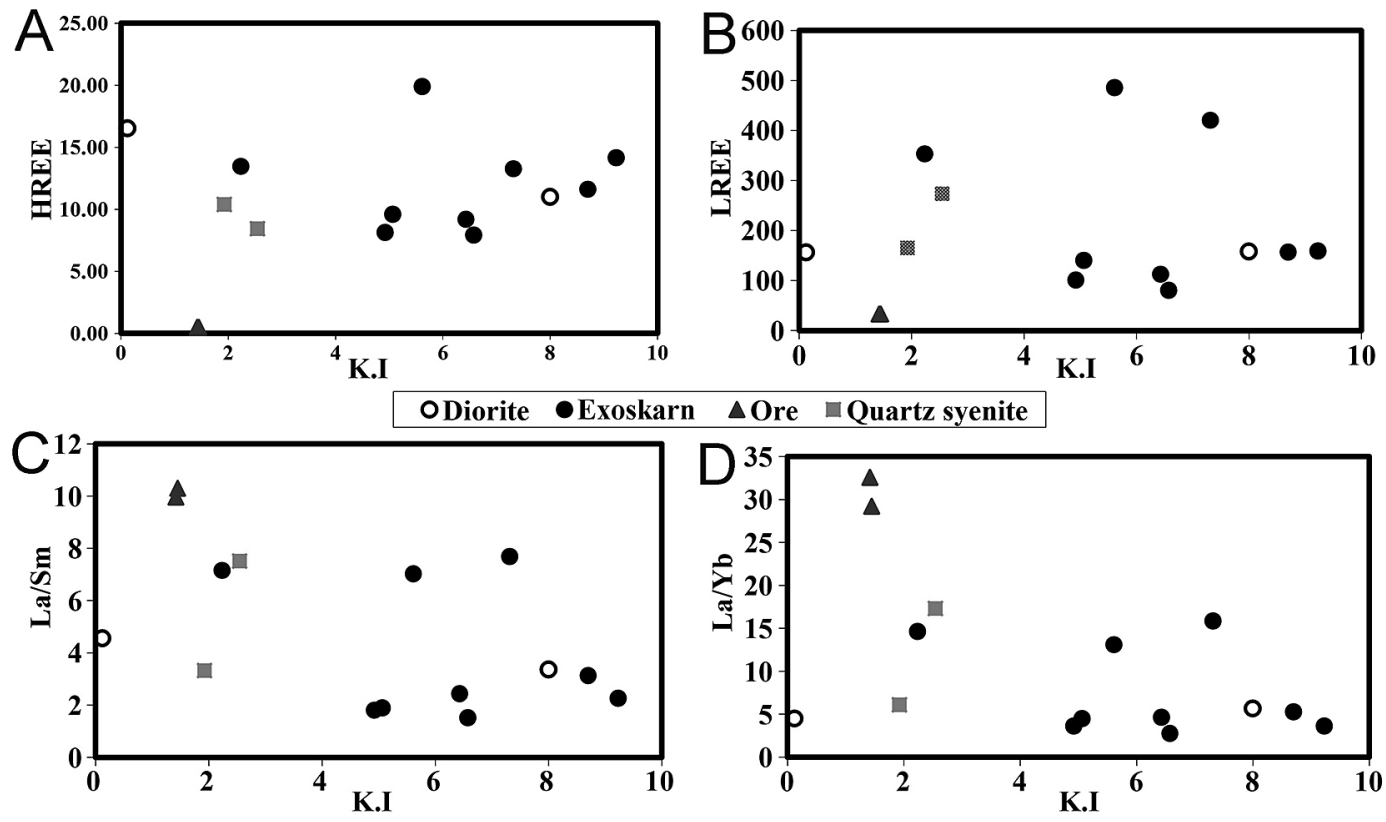

Fig. 8. Relationships between: A - K.I. and HREE; B - K.I. and LREE; C - K.I. and (La/Sm); D - K.I. and (La/Yb) ${ }_{n}$.
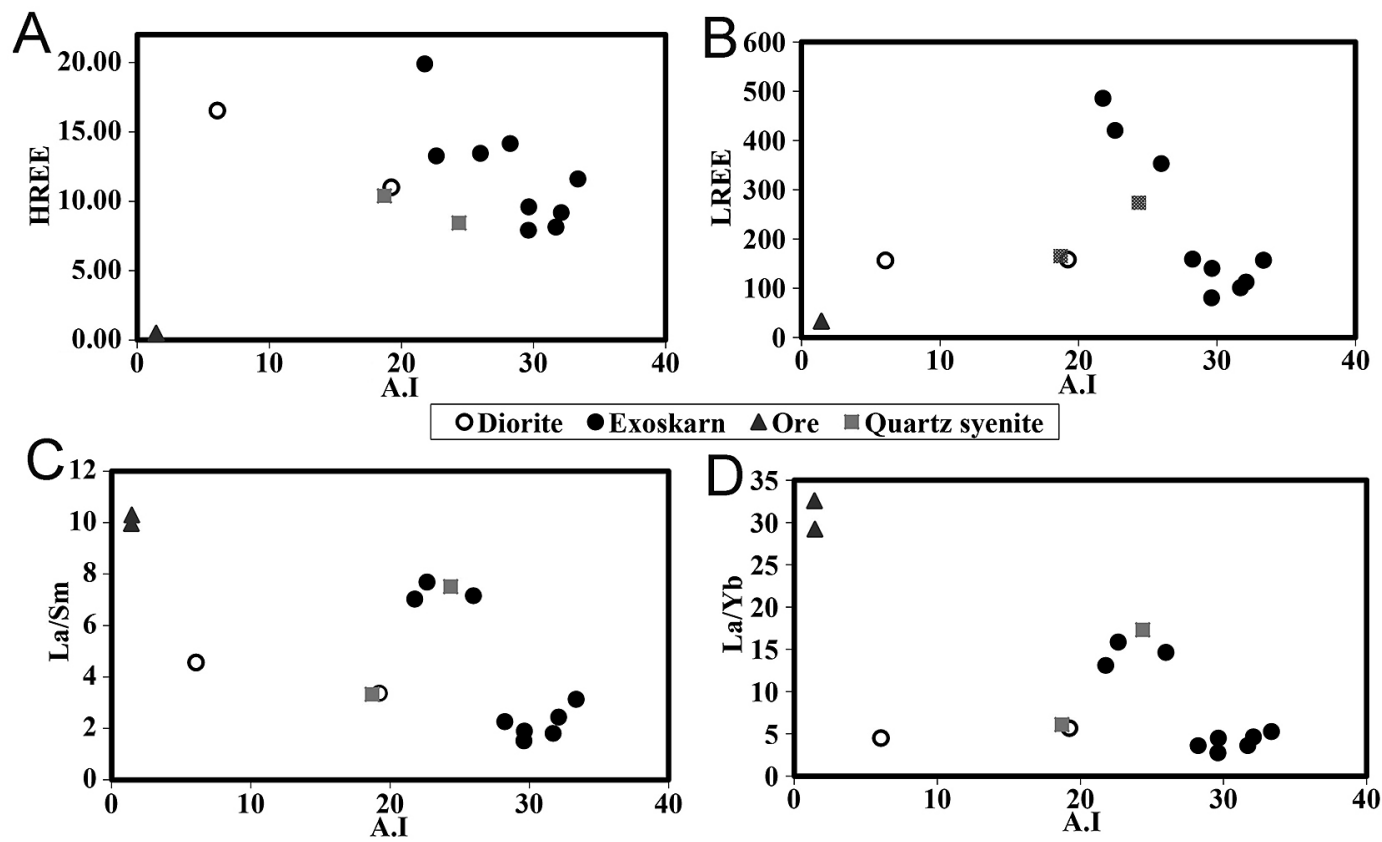

Fig. 9. Relationships between: A - A.I. and HREE; B - A.I. and LREE; C - A.I. and (La/Sm) ${ }_{n}$; - A.I. and (La/Yb) . 

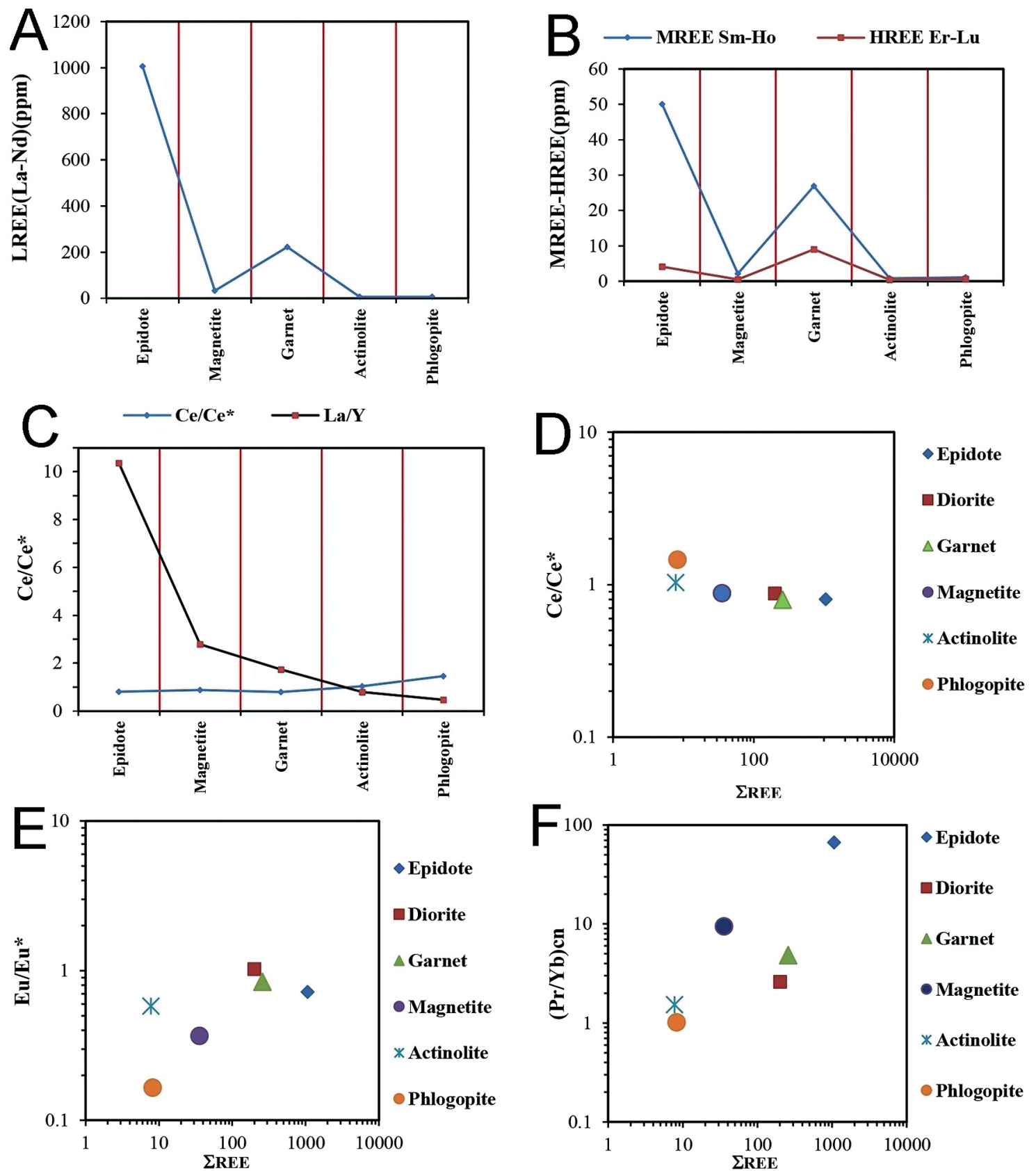

Fig. 10. Concentration variations of: A - LREEs; B - MREEs, HREEs; C - variations of La/Y-Ce/Ce*; D - Relationship between Ce/Ce* vs $\sum$ REE; E - Eu/Eu* vs $\sum R E E ; ~ F-(P r / Y b) c n$ vs $\sum R E E$.

net (from the exoskarn), actinolite and phlogopite (from the exoskarn neighbouring the diorite host rock) were selected and analysed. These minerals, along with oxides of $\mathrm{Fe}$, are important scavengers for REEs and can be used as indicators of stages of skarnisation such as prograde or retrograde conditions. Plotting of concentration variations of LREEs, MREEs and HREEs of these minerals elucidates two important points for the distribution of REEs (Fig. 10A-B). The distribution patterns of LREEs, MREEs, HREEs and REEs in minerals vary accord- ing to mineral in comparison with the diorite host rocks.

Except for HREEs, other parameters show an enrichment in epidote while an outstanding depletion is seen in magnetite, actinolite and phlogopite. Based on results of chemical analyses, anomalous levels of REEs in epidote are $\Sigma$ REE La-Lu = 1060.51 ppm, $\Sigma$ LREE La-Nd = 1006.4 ppm, $\Sigma$ MREE Sm-Ho = 50ppm, $\Sigma$ HREE Er-Lu $=4.11 \mathrm{ppm}$ and $\mathrm{La} / \mathrm{Y}=10.37$ (Table 7). The calculation of Eu and Ce anomalies (Taylor \& McLennan, 1985) shows that the anomaly 
Table 7. Results of chemical analyses for rare earth elements of epidote, magnetite, garnet, actinolite and phlogopite in the Baba Ali deposit.

\begin{tabular}{|c|c|c|c|c|c|c|c|c|c|c|c|c|c|c|}
\hline \multirow{2}{*}{ Mineral } & \multicolumn{14}{|c|}{ [ppm] } \\
\hline & $\mathrm{La}$ & $\mathrm{Ce}$ & $\operatorname{Pr}$ & $\mathrm{Nd}$ & Sm & $\mathrm{Eu}$ & Gd & $\mathrm{Tb}$ & Dy & Ho & Er & $\mathrm{Tm}$ & $\mathrm{Yb}$ & $\mathrm{Lu}$ \\
\hline Epidote & 364 & 498 & 39. & 105 & 15.45 & 3.88 & 17.4 & 2.25 & 9.71 & 1.31 & 2.74 & 0.2 & 1.07 & 0.1 \\
\hline Magnetite & 10.6 & 16.4 & 1.3 & 4.7 & 0.66 & 0.09 & 0.85 & 0.005 & 0.53 & 0.02 & 0.21 & 0.02 & 0.25 & 0.005 \\
\hline Garnet & 75.3 & 106.5 & 9.6 & 30.7 & 6.42 & 1.89 & 7.24 & 1.35 & 8.34 & 1.62 & 4.29 & 0.61 & 3.58 & 0.53 \\
\hline Actinolite & 1.9 & 3.4 & 0.2 & 1 & 0.2 & 0.04 & 0.22 & 0.005 & 0.32 & 0.02 & 0.16 & 0.02 & 0.26 & 0.005 \\
\hline Phlogopite & 1.3 & 3.7 & 0.2 & 1.3 & 0.24 & 0.015 & 0.32 & 0.005 & 0.45 & 0.005 & 0.21 & 0.02 & 0.41 & 0.005 \\
\hline Mineral & $\mathrm{Ce} / \mathrm{Ce}^{*}$ & * Eu/l & $\mathrm{Eu}^{*}$ & $\begin{array}{c}\text { LREE } \\
(\mathrm{La}-\mathrm{Nd})\end{array}$ & $\begin{array}{c}\text { MREE } \\
\text { (Sm- } \\
\mathrm{Ho})\end{array}$ & $\begin{array}{l}\text { HREE } \\
\text { (Er-Lu) }\end{array}$ & $\begin{array}{r}\Sigma \mathrm{R} \\
(\mathrm{La}-\end{array}$ & & $\mathrm{La} / \mathrm{Y}$ & $\begin{array}{l}(\mathrm{La} / \\
\mathrm{Sm}) \mathrm{n}\end{array}$ & $\begin{array}{l}(\mathrm{La} / \\
\mathrm{Yb}) \mathrm{n}\end{array}$ & & $\begin{array}{l}\mathrm{Gd} / \\
\mathrm{Yb}) \mathrm{n}\end{array}$ & $\begin{array}{l}(\mathrm{Pr} / \\
\mathrm{Yb}) \mathrm{n}\end{array}$ \\
\hline Epidote & 0.801 & 0.72 & & 1006.4 & 50 & 4.11 & 106 & 0.5 & 10.37 & 15.11 & 234.35 & & 13.17 & 66.65 \\
\hline Magnetite & 0.878 & 0.36 & & 33.01 & 2.155 & 0.485 & 35 & 65 & 2.78 & 10.30 & 29.20 & & 2.75 & 9.48 \\
\hline Garnet & 0.796 & 0.84 & & 222.11 & 26.86 & 9.01 & 257 & .98 & 1.73 & 7.52 & 14.48 & & 1.63 & 4.85 \\
\hline Actinolite & 1.032 & 0.58 & & 6.52 & 0.805 & 0.445 & 7. & & 0.79 & 6.09 & 5.034 & & 0.68 & 1.53 \\
\hline Phlogopite & 1.461 & 0.16 & & 6.53 & 1.035 & 0.645 & 8. & & 0.46 & 3.47 & 2.184 & & 0.63 & 1.01 \\
\hline
\end{tabular}

values range between $0.79-1.46$ and $0.16-0.84$, respectively (Table 7). The fractionation degree REEs between REEs with $(\mathrm{La} / \mathrm{Yb})_{n^{\prime}}(\mathrm{La} / \mathrm{Sm})_{\mathrm{n}}$ and $(\mathrm{Gd} /$ $\mathrm{Yb})_{\mathrm{n}}$ ratios in epidote reaches the maximum value. Epidote can show significant enrichment of LREE (Ferry et al, 2003). The low ratio $(\mathrm{La} / \mathrm{Yb})_{n^{\prime}}(\mathrm{La} / \mathrm{Sm})_{n}$ and $(\mathrm{Gd} / \mathrm{Yb})_{\mathrm{n}}$ in garnet is due to the formation of garnet in early stages of skarnisation that occurred mainly under dry and prograde conditions. Replacement of the prograde assemblage, i.e., garnet and pyroxene which formed under temperatures of $500-550^{\circ} \mathrm{C}$ (Zamanian, 2003) and early stage hydrothermal minerals along with magnetite indicate that magnetite mineralisation occurred at relatively lower temperatures and during late stages. The inferred temperature of the Fe mineralisation in the Baba Ali deposit is in the range of $350-400^{\circ} \mathrm{C}$. Garnet shows a low ratio $(\mathrm{La} / \mathrm{Yb})_{\mathrm{n}^{\prime}}(\mathrm{La} / \mathrm{Sm})_{\mathrm{n}}$ and $(\mathrm{Gd} /$
$\mathrm{Yb})_{\mathrm{n}}$ and generally reveals REE enrichment. EPMa analysis of magnetite from the Baba Ali deposit shows a rather pure magnetite phase. The absence of impurities such as $\mathrm{Mg}, \mathrm{Mn}, \mathrm{Zn}, \mathrm{Ni}, \mathrm{Ti}, \mathrm{V}$ and $\mathrm{Cr}$ is indicative of low temperatures during formation of magnetite (Ramdohr, 1980).

Epidote has the highest La/Y values (Fig. 10C). This diagram has two different parts: $\mathrm{La} / \mathrm{Yb}>1$ and $\mathrm{La} / \mathrm{Yb}<1$ indicating alkaline and acidic condition of metasomatism, respectively. Because the REEs leach from acidic parts and are then deposited (due to the buffering of hydrothermal solutions near carbonate veins of diorite) in the basic parts, the REE diagram shows the best correlation with the La/Y diagram. The contradiction in magnetite, in spite of their elevated basic conditions and lower REE concentrations, was linked to the purity of magnetite which could not concentrate REE in their structure
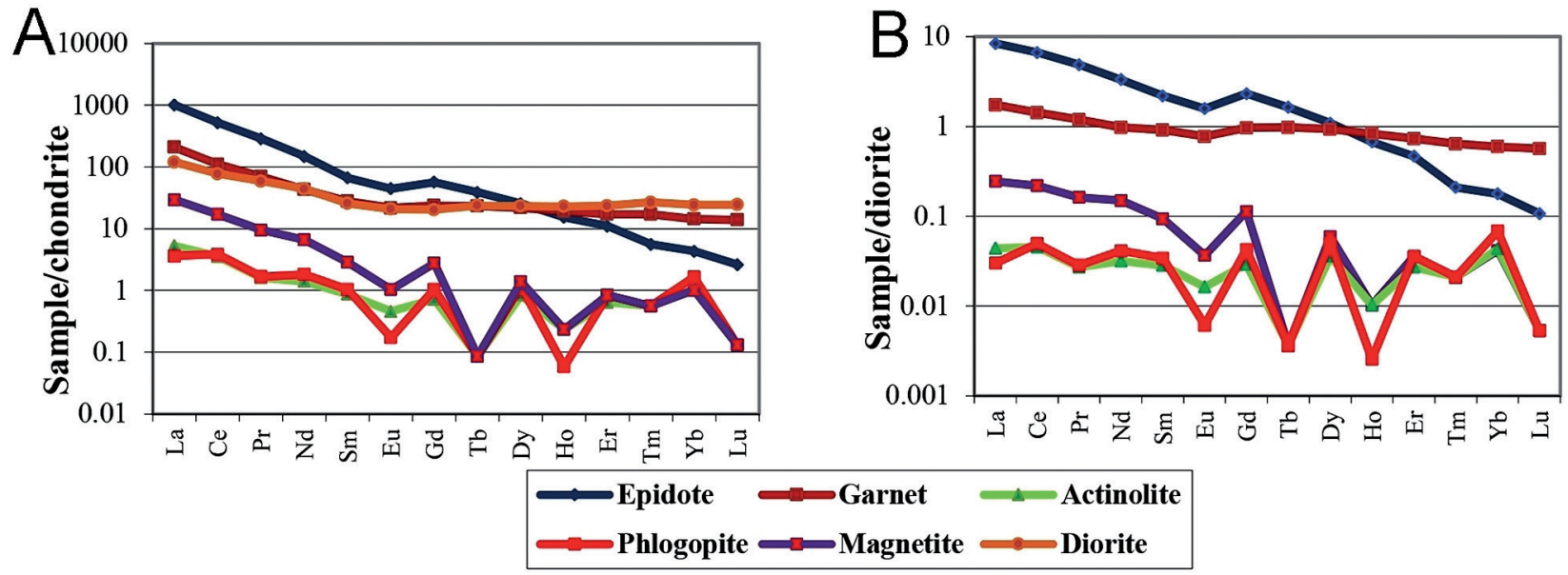

Fig. 11. A - Chondrite-normalised REE patterns (by Taylor \& McLennan, 1985) of minerals and diorite in the Baba Ali deposit; B - Original rock-normalised REE patterns of minerals. 
or fixation of these elements by epidote before they reached the ore zone. In view of the fact that in the Baba Ali the host rock is diorite this can be likened to a sensitive litmus paper for deciding the origin of the fluids. Thus, it can be a sensitive tracer for hydrothermal fluids with relatively low REE concentrations. This is because the hydrothermal fluids were of meteoric water origin and have very low REE concentrations. In contrast, hydrothermal fluids of magmatic in origin show an increase in $\Sigma$ REE, $(\mathrm{Pr} / \mathrm{Yb})_{\mathrm{cn}^{\prime}} \mathrm{Ce} / \mathrm{Ce}^{*}$ and $\mathrm{Eu} / \mathrm{Eu}^{*}$ values (Kato, 1999). The origin of the hydrothermal fluids, magmatic water or meteoric water, can be decided based on changes in REE abundances and patterns between diorite host rock and other lithounits. Utilising the three parameters $\mathrm{Ce} / \mathrm{Ce}^{*}, \mathrm{Eu} / \mathrm{Eu}^{*}$ and $(\mathrm{Pr} / \mathrm{Yb})$ in minerals show that the hydrothermal fluids through which magnetite, actinolite and phlogopite formed had low REE concentrations relative to the diorite rock, while hydrothermal fluids from which epidote was derived had high REE concentration and $(\mathrm{Pr} / \mathrm{Yb})_{\mathrm{n}}$ relative to the diorite rock (Fig. 10DF). These REE signatures indicate that hydrothermal fluids responsible for epidote and garnet were mostly of magmatic origin and for magnetite, actinolite and phlogopite were of magmatic origin with low REE concentrations or that meteoric water was involved in the formation of these minerals. The chondrite-normalised (Taylor \& McLennan, 1985) and the original rock-normalised REE patterns of minerals in the Baba Ali deposit show high LREE and low HREE in comparison to the diorite host rock in epidote and garnet (Fig. 11A-B).

\section{Conclusions}

The main results of the present study are:

1) The distribution patterns of LREEs and MREEs show a distinct depletion in the ore zone in comparson to the quartz syenite, altered diorite and exoskarn while represent a great enrichment in skarn facies in proximity to the ore body contact and declining towards the altered diorite host rock.

2) Skarn zones exhibit two distinctive parts: 1) a part that has La/Y $>1$ which is adjacent to the ore body and; 2) a portion with $\mathrm{La} / \mathrm{Y}<1$ which borders altered diorite. These two divisions indicate basic and acidic conditions of hydrothermal alteration during skarnisation, respectively.

3) The skarn zone, on the basis of REE values and Ce anomalies, can be divided into two distinct parts: 1) a leached zone showing positive Ce anomalies with low values of REEs that indi- cates acidic conditions of ore-forming fluids and field; 2) an enrichment zone that has an alkaline $\mathrm{pH}$, negative $\mathrm{Ce}$ anomalies and high REE values.

4) Low REEs concentration in the ore zone could be due to the purity of the magnetite phase.

5) The low ratio $(\mathrm{La} / \mathrm{Yb})_{\mathrm{n}^{\prime}}(\mathrm{La} / \mathrm{Sm})_{\mathrm{n}}$ and $(\mathrm{Gd} / \mathrm{Yb})_{\mathrm{n}}$ in garnet was due to formation of garnet during early stages of skarnisation that occurred mainly under dry and prograde conditions.

6) The values of REE signatures indicate that hydrothermal fluids responsible for epidote and garnet were mostly of magmatic origin and for magnetite, actinolite and phlogopite were of magmatic origin with low REE concentrations or that meteoric water was involved in the formation of these minerals.

7) Based on changes in REE patterns between diorite host rock and other lithounits a dual magmatic and meteoric origin for hydrothermal fluids can be deduced for the ore-forming fluid in the Baba Ali skarn deposit.

\section{Acknowledgments}

The present work was supported financially by the Research Bureau of Lorestan University, the authorities of whom we wish to thank. We are also grateful to anonymous reviewers for commenting on an earlier typescript and supplying valuable suggestions.

\section{References}

Amiri, M., 1995. Petrography of the Almouglagh. University of Tarbiat-e-Moalem, Tehran, Iran, 231 pp. (in Persian)

Asadi, S., 2009. Study of iron mineralization in metamorphic rock in Kohe germez - Kohe sorkh (Qatruyeh). University of Shiraz, Shiraz, Iran, 154 pp. (in Persian)

Aubert, D. Stille, P. \& Probst, A., 2001. REE fractionation during granite weathering and removal by waters and suspended loads: $\mathrm{Sr}$ and $\mathrm{Nd}$ isotopic evidence. Geochimica et Cosmochimica Acta 65, 387-406.

Barud, J., 1975. Geological Map of the Kermanshahan Quadrangle (1:250,000). Geological Survey of Iran, Tehran.

Bellon, H. \& Barud, J., 1975. Donnes nouvellexs sur le domaine metamorphique du Zagros (Zone de S-S au niveau de Kermanshah-Hamadan (Iran); Nature, age et interpretation des series metamorphiques et des intrusious, evolution structurale. Faculty of Science, Orsay Paris, 14 pp. (in French)

Brooking, D.G., 1984. Geochemical aspects of radioactive waste disposal. Springer, New York, $374 \mathrm{pp}$.

Crinci, J. \& Jurkowic, I ., 1990. Rare earth elements in Triassic bauxites of Croatia Yugoslavia. Travaux 19, 239-248. 
Darvishzadeh, A., 1992. Geology of Iran. Nashre Danesh, Tehran, Iran, 901 pp. (in Persian)

Einaudi, M.T. Meinert, L.D. \& Newberry, R.J., 1981. Skarn Deposits. Economic Geology, 75th Anniversary Volume, 317-391.

Emami, M.H., 2000. Magmatism in Iran. Geological Survey of Iran, Tehran, Iran, 608 pp. (in Persian)

Frei, D., Liebscher, A., Wittenberg, A. \& Shaw, C.S.J., 2003. Crystal chemical controls on rare earth element partitioning between epidote- group minerals and melt: An experimental and theoretical study. Contributions to Mineralogy and Petrology 146, 192-204.

Green, G.R. Ohmoto, H. Date, J. \& Takahashi, T., 1983. Whole- rock oxygen isotope distribution in the Fukazawa-Kosaka area, Hokuroku district, Japan and its potential application to mineral exploration. Economic Geology. Monogr. 5, 395-411.

Hashiguchi, H. Yamada, R. \& Inoue, T., 1983. Practical application of low $\mathrm{Na}_{2} \mathrm{O}$ anomalies in footwall acid lava for delimiting promising areas around the Kosaka and Fukazawa Kuroko deposits, Akita Prefecture, Japan. Economic Geology. Monogr. 5, 387-394.

Ishihara, S., 1981. The Granitoid Series and mineralization. Economic Geology 75, 458-484.

Ishikawa, Y. Sawaguchi, T. Iwaya, S. \& Horiuchi, M., 1976. Delineation of prospecting targets for Kuroko deposits based on modes of volcanism of underlying dacite and alteration halo. Mining Geology 26, 105-117.

Karadag, M. Kupeli, S. Aryk, A. Ayhan, A. Zedef, V. \& Doyen, A., 2009. Rare earth elements (REE) geochemistry and genetic implications of the Mortas bauxite deposit (Seydisehir/Konya-Southern Turkey). Chemie der Erde Geochemistry 69, 143-159.

Kato, Y., 1999. Rare earth elements as an indicator to origins of skarn deposits, example of the Kamioka $\mathrm{Zn}-\mathrm{Pb}$ and Yoshiwara-Sannotake (Cu-Fe) deposit in Japan. Resource Geology 49, 183-198.

Kikawada, Y., 2001. Experimental studies on the mobility of lanthanides accompanying alteration of andesite by acidic hot spring water. Chemical Geology 176, 137-149.
Knarchenko, S.M. \& Pokrovsky, B.G., 1995. The tomtor alkaline ultrabasic massif and related REE-Nb deposit, Northern Siberia. Economic Geology 90, 676-689.

Pollard, P.J., 1995. A special issue devoted to the geology of rare metal deposits, geology of rare metal deposits: An introduction and overview. Economic Geology 90, 489-494.

Rard, J.A., 1988. Aqueous solubility's of praseodymium, Europium and lutetium sulfates. Journal of Solution Chemistry 17, 499-517.

Ramdohr, P., 1980. The ore minerals and their intergrowth. $2^{\text {nd }}$ ed. Pergamon Press, London, 1205 pp.

Rolland, Y. Cox, S. Boullier, A. \& Pennacchioni, G., 2003. Rare earth and trace element mobility in mid-crustal shear zones: insights from the Mont Blanc Massif (Western Alps). Earth and Planetary Science Letters 214, 203-219.

Rollinson, H., 1993. Using Geochemical data: Evolution, presentation, interpretation. Longman, London, $652 \mathrm{pp}$.

Taylor, Y. \& McLennan, S.M., 1985. The Continental Crust: Its Composition and Evolution . Blackwell, Oxford, 312 pp.

Wood, S.A., 1990. The aqueous geochemistry of the rare-earth elements and Yttrium. Theoretical predictions of speciation in hydrothermal solutions to $350^{\circ} \mathrm{C}$ at saturation water vapor pressure. Chemical Geology 88, 99-125.

Yusoff, Z.M., Ngwenya, B.T. \& Parsons, I., 2013. Mobility and fractionation or REE during deep weathering of geochemically contrasting granites in a tropical setting, Malaysia. Chemical Geology 349-350, 71-86.

Zamanian, H., 2003. Iron mineralization related to the Almoughlagh and south Ghorveh batholiths with specific refrence ti the Baba Ali and Gelali deposits. University of Pune, 220 pp.

Zamanian, H. \& Asadollahi, B., 2013. Geochemistry and ore potential of the Almoughlagh batholiths, Western Iran. Geologos 19, 229-242.

Manuscript submitted 30 May 2015 Revision accepted 15 December 2015 